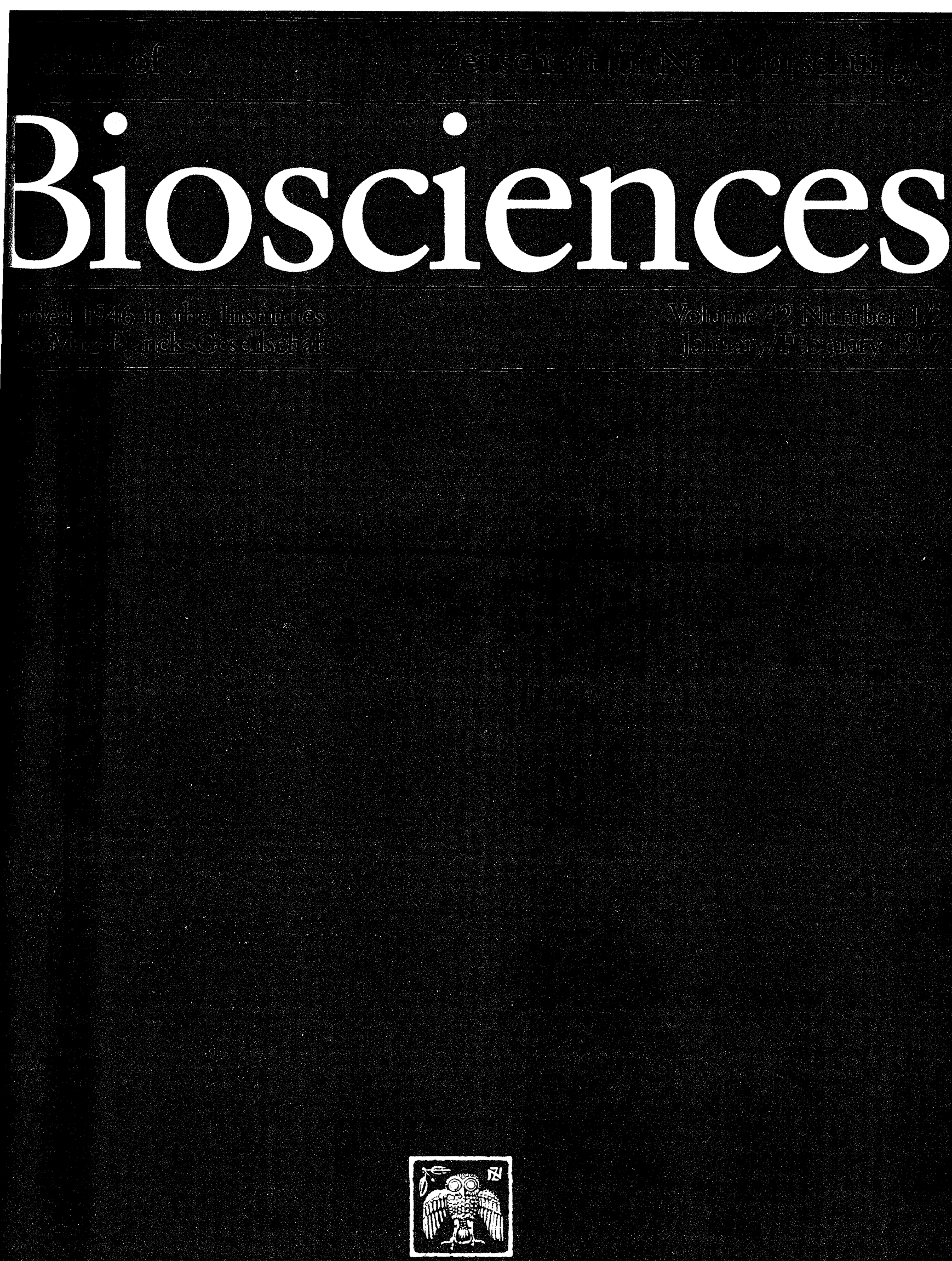




\section{ZEITSCHRIFT FÜR NATURFORSCHUNG}

Section C

A Journal of Biosciences

ISSN 0341-0382

Managing Editor:

H. Hausen, Tübingen

Council:

E. Bünning, Tübingen

A. Butenandt, München

M. Eigen, Göttingen

\section{Editors:}
A. Hager, Tübingen
K. Hahlbrock. Köln
W. Hasselbach, Heidelberg
P. Karlson, Marburg
F. Kaudewitz, München
J. Klein, Tübingen
J. St. Schell, Köln
E. Wecker, Würzburg

\section{Associate Editors:}

N. Amrhein, Bochum

B. A. Askonas, London

W. Barz, Münster

P. Böger, Konstanz

G. Bornkamm, Freiburg

D. Bückmann, Ulm

K. G. Götz, Tübingen

G. Gottschalk, Göttingen

P. Gruss, Heidelberg

G. Isenberg, Köln

R. Jaenicke, Regensburg

V. ter Meulen, Würzburg

G. F. Meyer, Tübingen

M. Rajewsky, Essen

H. Schimassek, Heidelberg

D. Schulte-Frohlinde, Mühlheim/R.

G. Schulz, Freiburg

F. F. Seelig, Tübingen

J. Seelig, Basel

H. Simon, München

W. Steglich, Bonn

H. Stieve, Aachen

J. Suko, Wien

A. Trebst, Bochum

G. Weissenböck, Köln

G. Wick, Innsbruck

V. Zimmermann, Würzburg

\section{Information for Contributors}

Contributions to Z. Naturforsch., Section C (biological sciences), may be (i) original papers, (ii) research notes not exceeding two pages in print and (iii) reports on current research of special interest. Two copies of each contribution should be sent to Dr. Helga Hausen, P. O. Box 2645, D-7400 Tübingen. (Section B (chemical sciences): Dr. Heide Voelter, P.O. Box 2645, D-7400 Tübingen; Section A (physical sciences): Mrs. Tamara Littmann, Lenzhalde 21, D-7082 Oberkochen).

Contributors are encouraged to suggest possible reviewers of their papers. The manuscript should be type written using double spacing throughout.

The title should be concise but informative. The names of the authors, with first names and initials, and of the institution where the work was carried out follow the title. A running title with not more than 60 characters should be indicated if the title is longer than this.

In a footnote on the first page, please give an address for reprint requests.

The title, a selfconsistant abstract, suitable for direct use by the abstracting journals (no references to the main text), and five keywords, all in English, must precede the main text of each contribution.

The main text should meet the highest standards as to novelty of the material, organization and conciseness. A qualified colleague and, if the text is in a foreign language, a person who thoroughly knows it, should have been given the opportunity to check the paper before its submission for publication.

Papers, reporting mainly spectroscopic, X-ray or other data of no general relevancy should not be submitted.

References and footnotes should be numbered (e.g. [1]) and listed at the end of the paper (e.g. [1] A. Meyer, Z. Naturforsch. 30c, 633 (1976)).

Tables with the appropriate captions and a list of the figure legends should follow at the end of the paper.

Allowance should be made for the reduction in printing of the drawings (line thickness, lettering!). Original drawings larger than $21 \times 30 \mathrm{~cm}$ should be replaced by copies of reduced size, when the manuscript is submitted and only be sent in when the manuscript is accepted. On all illustrations, the figure number and the author's name must be written in pencil.

The authors will receive page proofs.

Changes in the text after acceptance of the paper and drawings not fit for direct reproduction cause delay and create extra costs which may be charged to the author. 50 reprints are free of charge.

\section{Information for Subscribers}

The subscription prices per year are for normal subscribers:

$\begin{array}{lll}\text { Section A } & \text { Section B } & \text { Section C } \\ \text { DM 510.- } & \text { DM 610.- } & \text { DM 425.- }\end{array}$

for authors and their institutions if they order directly from the publishers:

$\begin{array}{lll}\text { Section A } & \text { Section B } & \text { Section C } \\ \text { DM 408.- } & \text { DM 488.- } & \text { DM 340.- }\end{array}$

plus postage and handling

$\begin{array}{lll}\text { Section A } & \text { Section B } & \text { Section C } \\ \text { DM 35.- } & \text { DM 35.- } & \text { DM 25.- }\end{array}$

Single copies and back-numbers are available.

Subscriptions will remain standing for the following year unless cancellations are made by postage October 1st.

\section{Informations for Advertisers}

The price for a small advertisement (breadth $43 \mathrm{~mm}$, height $57 \mathrm{~mm}$ ) in all three sections of the journal is DM 60.-.

For larger advertisments please order the price list from the publishers.

VERLAG DER ZEITSCHRIFT FÜR NATURFORSCHUNG, TÜBINGEN

P. O. Box 2645, D-7400 Tübingen (Postscheck-Konto Stuttgart 8039-700). 


\section{ZEITSCHRIFT FÜR}

\section{NATURFORSCHUNG}

\section{SECTION C}

\section{A EUROPEAN JOURNAL OF \\ BIOSCIENCES}

Council

E. BÜNNING,Tübingen

A. ButenandT, München

M. EIGEN, Göttingen
Editorial Board

A. HAGER, Tübingen

K. HAHLBROCK, Köln

W. HASSELBACH, Heidelberg

P. KARLSON, Marburg

F. KAUdEwitz, München

J. KLEIN, Tübingen

J. ST. SCHELL, Köln

E. WeCKER, Würzburg

Advisory Editorial Board

N. Amrhein, Bochum

B. A. Askonas, London

W. BARz, Münster

P. BöGER, Konstanz

G. BornKamm, Freiburg

D. BÜCKMANN, Ulm

K. G. Götz, Tübingen

G. GotTSCHALK, Göttingen

P. GRuss, Heidelberg
G. IsENBERG, Köln

R. JAENICKE, Regensburg

V. TER Meulen, Würzburg

G. F. MEYER, Tübingen

M. RAJEWSKY, Essen

H. SCHIMASSEK, Heidelberg

D. SCHUlte-Frohlinde, Mühlheim/R.

G. SCHULZ, Freiburg

F. F. SeElig, Tübingen
J. Seelig, Basel

H. Simon, München

W. STEGLich, Bonn

H. Stieve, Aachen

J. Suko, Wien

A. Trebst, Bochum

G. WeISSENBöcK, Köln

G. WICK, Innsbruck

V. ZIMMERMANN, Würzburg

EDITED IN COLLABORATION

WITH THE INSTITUTES OF THE MAX-PLANCK-GESELLSCHAFT

\section{VERLAG DER ZEITSCHRIFT FÜR NATURFORSCHUNG TÜBINGEN}


Anschrift des Verlages: Postfach 26 45. D-7400 Tübingen Satz und Druck: Allgäuer Zeitungsverlag GmbH, Kempten

Nachdruck - auch auszugsweise - nur mit schriftlicher Genehmigung des Verlages

Section a

Physics, Physical Chemistry, Cosmic Physics

Section $b$

Inorganic and Organic Chemistry 
Stereochemistry and Mechanism of Reactions Catalyzed by Tyrosine Phenol-Lyase from Escherichia intermedia

M. M. Palcic, S.-J. Shen, E. Schleicher, H. Kumagal, S. Sawada, H. Yamada, and H. G. FLoss

Distant Precursors of Benzylisoquinoline Alkaloids and Their Enzymatic Formation

M. RUEFFER and M. H. ZENK

Characterization of $2 \beta(R)-17-\mathrm{O}-$ Acetylajmalan: Acetylesterase - a Specific Enzyme Involved in the Biosynthesis of the Rauwolfia Alkaloid Ajmaline

L. Polz, H. SchÜBeL, and J. StöcKigT

333

Induction and Characterization of a NADPH-Dependent Flavone Synthase from Cell Cultures of Soybean

G. Kochs and H. Grisebach

Proposal for the Mechanism of Action of Urocanase. Inference from the Inhibition by 2-Methylurocanate

E. GERLINGER and J. RÉTEY

349

Re-Investigation of the Protein Structure of Coenzyme $B_{12}$-Dependent Diol Dehydrase K. Tanizawa, N. Nakajima, T. Toraya, H. Tana$\mathrm{KA}$, and K. SoDA 
Methanogenesis from Acetate by Methanosarcina barkeri: Catalysis of Acetate Formation from Methyl Iodide, $\mathrm{CO}_{2}$, and $\mathrm{H}_{2}$ by the Enzyme System Involved

K. Laufer, B. Eikmanns, U. Frimmer, and R. K. THAUER 360

Divergent Evolution of $5 \mathrm{~S}$ rRNA Genes in Methanococcus

G. WICH, L. SibOLD, and A. BöcK

Characterization of Some Claviceps Strains Derived from Regenerated Protoplasts

B. SchumanN, W. Maier, and D. Gröger 381

Phenylalanine and Tyrosine Biosynthesis in Sporeforming Members of the Order Actinomycetales H.-K. Hund, B. Keller, and F. Lingens

E. coli Maltodextrin Phosphorylase: Primary Structure and Deletion Mapping of the C-Terminal Site D. Palm, R. Goerl, G. Weidinger, R. Zeier, B. FisCHER, and R. SCHINZEL

Fermentation of D-Xylose to Ethanol by Bacillus macerans

H.-J. Schepers, St. Bringer-Meyer, and H. Sahm

Semicontinuous and Continuous Production of Citric Acid with Immobilized Cells of Aspergillus niger H. EIKMEIER and H. J. ReHM 408

Microbial Hydroxylation of Cedrol and Cedrene W.-R. Abraham, P. Washausen, and K. KIESLICH

6-Methylpurine, 6-Methyl-9- $\beta$-D-ribofuranosylpurine, and 6-Hydroxymethyl-9- $\beta$-D-ribofuranosylpurine as Antiviral Metabolites of Collybia maculata (Basidiomycetes)

K. Leonhardt, T. Anke, E. Hillen-Maske, and W. STEGLICH

Enzymatic Synthesis of Riboflavin and FMN Specifically Labeled with ${ }^{13} \mathrm{C}$ in the Xylene Ring H. Sedlmaier, F. Müller, P. J. Keller, and A. BACHER

A Vitamin $D_{3}$ Steroid Hormone in the Calcinogenic Grass Trisetum flavescens W. A. Rambeck, H. Weiser, and H. Zucker 430
Functional Group Recognition of Pheromone Molecules by Sensory Cells of Antheraea polyphemus and Antheraea pernyi (Lepidoptera: Saturniidae) H. J. Bestmann, W. Cai-Hong, B. Döhla, LiKedong, and K. E. Kaissling

Building Blocks for Oligonucleotide Syntheses with Uniformly Fragmentable $\beta$-Halogenated Protecting Groups (In German)

P. Lemmen, R. Karl, I. Ugi, N. Balgobin, and J.

ChatTopadhyaya

Experiments on the Optical Resolution of Conduramine Analogs by Enzymatic Transesterification in Organic Solvents (In German)

G. KRESZE and M. SABUNI

Steric Course of the Rhodium-Catalyzed Decarbonylation of Chiral 4-Methyl- $\left[1-{ }^{3} \mathrm{H}, 2-{ }^{2} \mathrm{H}_{1}\right]$ pentanal

H. Otsuka and H. G. Floss

Synthesis of Immobilized Peptide Fragments on Polystyrene-Polyoxyethylene for Affinity Chromatography (In German)

E. BAyer, H. Hellstern, and H. Eckstein

455

Biopterin Synthesis in Mouse Spleen during Bone Marrow Transplantation Correlates with Unimpaired Hemopoietic Engraftment

I. ZIEGLER and ST. THIERFELDER

461

In vivo Screening of Glutathione Related Detoxification Products in the Early State of Drug Development

A. Prox, J. Schmid, J. Nickl, and G. EngelHARDT

465

Synthesis and Complexing Features of an Artificial Receptor for Biogenic Amines (In German)

F. P. SCHMIDTCHEN

Metabolism of the Herbicide 2-(2,4-Dichlorophenoxy)-propionic Acid (Dichlorprop) in Barley (Hordeum vulgare)

G. Bärenwald, B. Schneider, and H.-R. SCHÜTTE

486

Site Directed Antisera to the D-2 Polypeptide Subunit of Photosystem II

R. Geiger, R. J. Berzborn, B. Depka, W. OettMEIER, and A. TREBST 


\title{
Distant Precursors of Benzylisoquinoline Alkaloids and their Enzymatic Formation
}

\begin{abstract}
Martina Rueffer and Meinhart H. Zenk
Lehrstuhl für Pharmazeutische Biologie, Universität München, Karlstraße 29, D-8000 München 2, Bundesrepublik Deutschland

Z. Naturforsch. 42 c, 319-332 (1987); received October 30, 1986

Dedicated to Professor Helmut Simon on the occasion of his 60th birthday

Berberis Species, Suspension Cultures, Cell-Free Systems, Benzylisoquinoline Alkaloids, Enzymes of Tyrosine Metabolism

The incorporation rates of labelled tyrosine, DOPA, tyramine, and dopamine have been investigated during the in vivo formation of the protoberberine alkaloid, jatrorrhizine, in callus cultures of Berberis canadensis. While tyrosine was equally well incorporated into both the isoquinoline $(54 \%)$ and benzyl $(46 \%)$ portions of the alkaloid, DOPA was almost exclusively $(91 \%)$ transformed into the isoquinoline moiety. However, tyramine $(25 \%)$ and to a lesser extent, dopamine $(15 \%)$ were incorporated into the aldehyde-derived, benzylic half of the isoquinoline molecule as well. In order to investigate further the precursory roles of these compounds, select enzymes involved in tyrosine metabolism in alkaloid-producing cell cultures have been studied. The occurrence of tyrosine decarboxylase, phenolase, transaminase, $p$-hydroxyphenylpyruvate decarboxylase, amineoxidase and methionine adenosyl transferase was demonstrated in suspension cells of Berberis. These enzymes were partially purified and a preliminary characterization was performed. In the light of these and previous data, the differential metabolism of tyrosine and DOPA in the early steps of isoquinoline alkaloid biosynthesis is discussed. Conclusive evidence as to the biosynthetic origin of the phenylacetaldehydes which furnish the benzylic moiety of the alkaloids is precluded by the presence of both amineoxidase and phenylpyruvate decarboxylase activities in these cultures.
\end{abstract}

\section{Introduction}

In 1910 Winterstein and Trier [1] suggested that two molecules of 3,4-dihydroxyphenylalanine (DOPA) may be modified in the plant to yield dopamine and 3,4-dihydroxyphenylacetaldehyde. These could subsequently condense to yield norlaudanosoline, already considered as a potential precursor for more complex isoquinoline alkaloids. LTyrosine is an immediate precursor of L-DOPA and numerous reports [see 2] have appeared demonstrating the incorporation of this primary amino acid into benzylisoquinoline-derived alkaloids. Chemical degradation of the benzylisoquinoline skeleton, which has been labelled by application of specifically labelled tyrosine, demonstrated in numerous cases that two molecules of tyrosine form the isoquinoline "upper" and benzylic "lower" portion of these compounds [2. 3]. In contrast, feeding experiments using specifically labelled DOPA demonstrated that this

Abbreviations: DOPA. 3,4-Dihydroxyphenylalanine; SAM, S-Adenosylmethionine.

Reprint requests to Dr. M. Rueffer.

Verlag der Zeitschrift für Naturforschung, D-7400 Tübingen 0341-0382/87/0400-0319 \$01.30/0 amino acid is metabolized solely via decarboxylation to dopamine, which is in turn incorporated almost exclusively into the upper isoquinoline portion of the benzylisoquinoline alkaloids [3]. While the formation of the isoquinoline part of the molecules in question seems to be clear, there is considerable confusion concerning the origin of the lower benzylic part. Reports [4] that DOPA is also incorporated via 3,4dihydroxyphenylpyruvic acid into the "lower" portion and postulation of norlaudanosolinecarboxylic acid as an intermediate, which was apparently experimentally supported by three other research groups [5-7], were refuted by in vivo [3] and in vitro $[8,9]$ experiments. Holland et al. [3] investigated the incorporation of $\mathrm{DL}-\left[3-{ }^{14} \mathrm{C}\right] \mathrm{DOPA}$ into 6 different isoquinoline alkaloids in 3 different plant species. In all cases incorporation was found predominantly $(93-99 \%)$ in the isoquinoline half of the target alkaloid. We [8, 9], on the other hand, discovered a specific enzyme which, in a stereospecific manner, condenses dopamine with 3,4-dihydroxy- and 4-hydroxyphenylacetaldehyde to yield (S)-norlaudanosoline and norcoclaurine respectively, ruling out the above postulated norlaudanosolinecarboxylic acid as an obligatory intermediate. 
This present study was therefore undertaken to further clarify the true nature of the distant precursors in the formation of the benzylisoquinoline system. This investigation was conducted in a dual manner, using callus and suspension cultures of Berberis, which are known to produce large amounts of protoberberine alkaloids of the jatrorrhizine type [10]. Firstly, the incorporation of distant potential precursors into the protoberberine alkaloids was checked. The advantage is that considerably higher rates of incorporation of precursors can be achieved with the callus system as compared to intact plants. Secondly, the enzymes of the tyrosine metabolic pathway were investigated in protoberberine producing cell suspension cultures to gain an insight into the formation of dopamine and the hydroxylated phenylacetaldehydes, the known precursors of the benzylisoquinolines. As already pointed out by Spenser [2], every known isoquinoline alkaloid contains one or more methyl or methylenedioxy groups. Both entities are derived from the S-methyl group of methionine. The surprisingly specific $\mathrm{O}$ - and $\mathrm{N}$-methyltransferases involved in the later steps of benzylisoquinoline modification have become increasingly known [11]. In an attempt to study the distant precursors of the isoquinoline alkaloids, we also included the enzyme responsible for the synthesis of S-adenosylmethionine (SAM) from L-methionine and ATP.

By using both of the approaches depicted above precursor feeding and enzyme studies - it was hoped to gain an insight into the nature of the true precursors and the enzymes involved in the formation of the building blocks of the benzylisoquinoline system.

\section{Materials and Methods}

\section{Plant material}

Callus and suspension cells of Berberidaceae, Papaveraceae, Menispermaceae and control species have been maintained in this laboratory for the past 12 years. The calli were grown on LS-medium [12] solidified with agar (1\%). The suspended cells were cultivated in 2.51 Fernbach flasks in a volume of $1000 \mathrm{ml}$ LS-medium on a gyratory shaker $(100 \mathrm{rpm})$ in diffuse light (750 lux) at $24^{\circ} \mathrm{C}$ and were subcultured at weekly intervals using about $10 \%$ inoculum $(\mathrm{v} / \mathrm{v})$. The cells were harvested immediately after reaching the stationary phase, frozen in liquid nitrogen and stored at $-20^{\circ} \mathrm{C}$.

\section{Chemicals}

Tyrosine, tyramine, DOPA, and dopamine were purchased from Fluka (Neu-Ulm), $p$-hydroxyphenylpyruvate from Sigma (München). All biochemicals were obtained from Boehringer (Mannheim). Palmatine was a kind gift of Prof. N. Nagakura (Kobe). The following chromatography gels were used: Sephadex G-25 and QAE-Sephadex (Pharmacia, Uppsala), DEAE-Matrex ${ }^{\mathrm{TM}}$ Cellufine (Amicon, Witten), TSK-HW 55S (Merck, Darmstadt), Hydroxylapatite (Bio-Rad, Richmond). TLC-Plates (Silica 60-Polygram sheets and Cellulose MN 300) were obtained from Macherey and Nagel (Düren). Rotiszint 22 (Roth, Karlsruhe) and Quickszint 2000 (Zinsser, Frankfurt) were used as scintillation cocktails. All other chemicals and solvents were purchased from Merck (Darmstadt) or Roth (Karlsruhe).

\section{Radiochemicals}

The following radiochemicals were purchased from Amersham-Buchler (Braunschweig): $\left[\mathrm{U}-{ }^{14} \mathrm{C}\right]$ tyrosine $(58 \mu \mathrm{Ci} / \mu \mathrm{mol}),\left[{ }^{14} \mathrm{COOH}\right]$ tyrosine $(58 \mu \mathrm{Ci} /$ $\mu \mathrm{mol}),\left[7-{ }^{14} \mathrm{C}\right]$ tyramine $(56 \mu \mathrm{Ci} / \mu \mathrm{mol}),\left[7-{ }^{14} \mathrm{C}\right] \mathrm{dop}-$ amine $(54 \mu \mathrm{Ci} / \mu \mathrm{mol}),\left[3-{ }^{14} \mathrm{C}\right] \mathrm{DOPA}(10.9 \mu \mathrm{Ci} / \mu \mathrm{mol})$, $\left[2,3-{ }^{3} \mathrm{H}\right]$ tyrosine $\quad(16 \mathrm{mCi} / \mu \mathrm{mol}), \quad\left[1-{ }^{14} \mathrm{CH}_{3}\right] \mathrm{meth}-$ ionine $(50 \mu \mathrm{Ci} / \mu \mathrm{mol}),\left[\mathrm{S}-\mathrm{C}^{3} \mathrm{H}_{3}\right]$ methionine $(70 \mathrm{mCi} /$ $\mu \mathrm{mol})$. [Ring $-{ }^{3} \mathrm{H}$ ]tyramine $(29.8 \mathrm{mCi} / \mu \mathrm{mol})$ was obtained from NEN (Dreieichenhain).

$\left[{ }^{14} \mathrm{COOH}\right]-p$-Hydroxyphenylpyruvate was synthesized by incubating $\left[{ }^{14} \mathrm{COOH}\right]$ tyrosine $(5 \mu \mathrm{Ci}$;

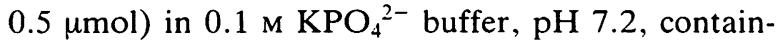
ing $1 \mathrm{mg}$ catalase (beef liver, Boehringer, Mannheim; 6000 units) and $30 \mu \mathrm{g}$ L-amino acid oxidase (Crotalus durissus, Boehringer, 0.2 units) in a total volume of $400 \mu \mathrm{l}$. After incubation for $4 \mathrm{~h}$ at $30^{\circ} \mathrm{C}$ the mixture was acidified with $0.2 \mathrm{~N} \mathrm{HCl}$ and extracted 5 times with $2 \mathrm{ml}$ ethylacetate. The keto acid was recovered from the organic phase and subsequently purified by TLC (Polygram) with the solvent system: benzene : dioxane : acetic acid $=90: 25: 4\left(R_{\mathrm{f}}\right.$ : $0.4)$. The yield of purified $p$-hydroxyphenylpyruvic acid under these conditions was $85 \%$.

\section{TLC-Systems}

The following solvent systems were used with Silica 60-Polygram sheets: ethylacetate:methylethylketone: formic acid: water $=50: 30: 10: 10$ (jatrorrhizine, $\left.R_{\mathrm{f}}: 0.80\right)$; chloroform:methanol:ammonia $=68: 18: 0.6$ (palmatine, $\left.R_{\mathrm{f}}: 0.52\right)$; chloroform: 
methanol $=95: 5$ (corydaldine, $R_{\mathrm{f}}: 0.73$ ); benzol: acetic acid $=8: 2$ (2,3-dimethoxyphthalic acid, $R_{\mathrm{f}}$ : 0.51 ); $n$-butanol: acetic acid: water $=4: 1: 5$ (upper phase) (tyramine, $R_{\mathrm{f}}: 0.43$; dopamine, $R_{\mathrm{f}}: 0.22$ ); chloroform: ethylacetate $=8: 2$ (4-hydroxyphenylacetaldehyde, $R_{\mathrm{f}}: 0.70 ; 3,4$-dihydroxyphenylacetaldehyde, $R_{\mathrm{f}}: 0.63$ ). For separation on Cellulose MN 300 plates the solvent system: $n$-butanol: acetic acid : water $=4: 1: 5$ (upper phase) (tyrosine, $R_{\mathrm{f}}: 0.29$; tyramine, $R_{\mathrm{f}}: 0.53$; DOPA, $R_{\mathrm{f}}: 0.24$; dopamine, $R_{\mathrm{f}}$ : 0.38 ) was used.

\section{Feeding procedure}

The labelled precursor $(50 \mu \mathrm{l}, 2.5 \mu \mathrm{Ci}, 0.05 \mu \mathrm{mol})$ was applied to a vigorously growing 14 day old callus culture of Berberis canadensis. The callus was allowed to metabolize for 5 days at $24^{\circ} \mathrm{C}$ in the dark. Thereafter the callus was harvested quantitatively and the major alkaloid, jatrorrhizine, was isolated and subsequently analyzed.

\section{Degradation of jatrorrhizine}

Callus tissue (approx. $0.3 \mathrm{~g} \mathrm{dwt}$ ) was extracted with $\mathrm{MeOH}(2 \times 20 \mathrm{ml})$. The extract was concentrated and chromatographed on Polygram Silica plates $(0.25 \mathrm{~mm}$; Macherey and Nagel, Düren) using the solvent system ethylacetate:methylethylketone : formic acid: water $=50: 30: 10: 10$ (jatrorrhizine, $\left.R_{\mathrm{f}}: 0.8\right)$. The alkaloid was eluted and methylated with dimethyl sulfate/acetonitrile. The resulting palmatine was appropriately diluted with carrier alkaloid (average: total of $30 \mu \mathrm{mol}$ ) and chromatographed with chloroform: methanol: $\mathrm{NH}_{4} \mathrm{OH}=$ $68: 18: 0.6$ as solvent (palmatine, $R_{\mathrm{f}}: 0.5$ ). The eluted palmatine was reduced with $\mathrm{NaBH}_{4}$ in $\mathrm{MeOH}$, the solvent evaporated and the residue taken up in $\mathrm{H}_{2} \mathrm{O}$ and extracted with ethylacetate. The organic layer was concentrated in vacuo and taken up in $2 \mathrm{ml} 10 \%$ $\mathrm{H}_{2} \mathrm{SO}_{4}$. The acidic solution was cooled in an ice water bath and $5 \mathrm{mg} \mathrm{KMnO}_{4}$ dissolved in $1 \mathrm{ml} \mathrm{H}_{2} \mathrm{O}$ were slowly added while stirring. After $2 \mathrm{~h}$ the mixture was acidified to $\mathrm{pH} 3$ and extracted with ethylacetate. This procedure yielded the lower benzylic portion of the alkaloid as 2,3-dimethoxyphthalic acid (10\% yield). TLC of the product in benzene: glacial acetic acid $=8: 2\left(R_{\mathrm{f}}: 0.5\right)$ and treatment with diazomethane yielded the methylated product. MS $(\mathrm{m} / \mathrm{z}) 254\left(\mathrm{M}^{+}\right), 223(100), 207,191$ and NMR $\left(\mathrm{CDCl}_{3}\right): 3.95$ (s), 405 (s), 7.15-7.19 (d), 7.51-7.55 (d). The aqueous phase was basified with $15 \%$ $\mathrm{NaOH}$ and extracted with chloroform. The organic layer was concentrated and chromatographed, resulting in the upper isoquinoline portion of the alkaloid, 6,7-dimethyl-1,2,3,4-tetrahydro-1-isoquinoline $=$ corydaline $(17 \%)$. MS: $207\left(\mathrm{M}^{+}, 100\right)$, 178, 150, 135; NMR $\left(\mathrm{CDCl}_{3}\right): 290(\mathrm{~m}), 3.48(\mathrm{~m}), 390$ (s), $6.65(\mathrm{~s}), 7.56(\mathrm{~s})$.

At each stage of purification the specific activity of the products was determined.

\section{Enzyme assays}

\section{Tyrosine decarboxylase}

The assay system consisted of $62.5 \mathrm{nmol} \mathrm{L-}$ $\left[{ }^{14} \mathrm{COOH}\right]$ tyrosine $\left(2.5 \times 10^{4} \mathrm{cpm}\right)$ and $50 \mathrm{nmol}$ pyridoxalphosphate in $1.6 \times 10^{-3} \mathrm{M} \mathrm{KPO}_{4}{ }^{2-}$ buffer $\mathrm{pH}$ 6.5 , and enzyme in a total volume of $300 \mu$ l, incubated in an Eppendorf vial for $1 \mathrm{~h}$ at $30^{\circ} \mathrm{C}$. The Eppendorf vial was then placed into a scintillation vial containing $0.2 \mathrm{ml}$ hyamine (Zinsser, Frankfurt) and subsequently sealed with a rubber stopper. The reaction was terminated by addition of $50 \mu \mathrm{l}$ of a $0.2 \mathrm{~N}$ perchloric acid solution which was injected into the Eppendorf vial. The evolving ${ }^{14} \mathrm{CO}_{2}$ was absorbed by the hyamine solution during a period of $1 \mathrm{~h}$ and the Eppendorf vial was subsequently discarded. Scintillator (Quickszint 2000; Zinsser, Frankfurt) was added and the sample was counted. The recovery rate of this assay was tested with labelled $\mathrm{Na}_{2}{ }^{14} \mathrm{CO}_{3}$ and averaged $90 \%$. Protein contents were determined by the method of Bradford [13] using bovine serum albumin as standard.

\section{Phenolase}

[Ring ${ }^{3} \mathrm{H}$ ]tyramine $10 \mathrm{nmol}\left(2 \times 10^{3} \mathrm{cpm}\right)$, ascorbate $50 \mu \mathrm{mol}, \mathrm{KPO}_{4}{ }^{2-}$ buffer $50 \mu \mathrm{mol}$ and enzyme (up to $1 \mathrm{mg}$ protein) were incubated in a total volume of $300 \mu \mathrm{l}$ for $1 \mathrm{~h}$ at $30^{\circ} \mathrm{C}$ and the reaction terminated by the addition of $300 \mu \mathrm{l}$ charcoal suspension (10 g/100 ml; dextran coated). The mixture was centrifuged for $5 \mathrm{~min}$ (Eppendorf system) and an aliquot of $300 \mu \mathrm{l}$ of the aqueous phase containing tritiated water was removed for liquid scintillation counting.

\section{Transaminase}

$\left[2^{\prime}, 3^{\prime}-{ }^{3} \mathrm{H}\right]$ Tyrosine or DOPA (synthesized from tyrosine by phenolase) $250 \mathrm{nmol}\left(10^{4} \mathrm{cpm}\right)$ were incubated in the presence of pyridoxalphosphate 
$750 \mathrm{nmol}, \alpha$-ketoglutarate $750 \mathrm{nmol}$ and enzyme (up to $2 \mathrm{mg}$ protein) in a total volume of $300 \mu \mathrm{l}$. The mixture was incubated for $1 \mathrm{~h}$ at $30^{\circ} \mathrm{C}$, the reaction terminated by addition of charcoal, and monitored as above.

\section{4. $p$-Hydroxyphenylpyruvate decarboxylase}

In $300 \mu \mathrm{l}$, the assay system contained $\left[{ }^{14} \mathrm{COOH}\right]-$ p-hydroxyphenylpyruvate $25 \mathrm{nmol}\left(10^{4} \mathrm{cpm}\right)$, thiamine pyrophosphate $50 \mathrm{nmol}, \mathrm{MgCl}_{2} 100 \mathrm{nmol}$, phosphate buffer $66 \mu \mathrm{mol}(\mathrm{pH} 7.0)$ and enzyme (up to $1 \mathrm{mg}$ protein). This mixture was incubated in an Eppendorf vial for $1 \mathrm{~h}$ at $30{ }^{\circ} \mathrm{C}$. The liberated ${ }^{14} \mathrm{CO}_{2}$ was assayed as in the case of the tyrosine decarboxylase.

\section{Amineoxidase}

In a total volume of $300 \mu \mathrm{l}$ [ ring. ${ }^{3} \mathrm{H}$ ] tyramine $10 \mathrm{nmol}\left(1.2 \times 10^{4} \mathrm{cpm}\right)$ in $50 \mu \mathrm{M} \mathrm{KPO}_{4}{ }^{2-}$ buffer and protein (up to $1 \mathrm{mg}$ ) were incubated for $40 \mathrm{~min}$ at $30{ }^{\circ} \mathrm{C}$. The reaction was terminated by the addition of $0.1 \mathrm{ml} 1 \mathrm{~N} \mathrm{HCl}$ and the mixture extracted with $400 \mu \mathrm{l}$ isoamyl alcohol ( $30 \mathrm{~min})$. After centrifugation (3 min) a $200 \mu \mathrm{l}$ aliquot of the organic phase was counted (Rotiszint; Roth, Karlsruhe) in order to determine the presence of any transformed $\left[{ }^{3} \mathrm{H}\right]-p$-hydroxyphenylacetaldehyde.

\section{ATP: L-Methionine-S-Adenosyltransferase}

The assay system contained in a total volume of $150 \mu \mathrm{l}: 5 \mu \mathrm{mol} \mathrm{KCl}, 5 \mu \mathrm{mol} \mathrm{MgCl}_{2}, 20 \mu \mathrm{mol}$ Trisbuffer, pH 8.5, $1 \mu \mathrm{mol}$ ATP, $10 \mathrm{nmol}$ [S$\mathrm{C}^{3} \mathrm{H}_{3}$ ] methionine $(60000 \mathrm{cpm})$ and up to $0.5 \mathrm{mg}$ protein. The reaction $\left(1 \mathrm{~h}\right.$ at $\left.37^{\circ} \mathrm{C}\right)$ was terminated by the addition of $50 \mu \mathrm{l}$ aliquots of the incubation mixture onto $1 \mathrm{~cm}^{2}$ pieces of filter paper (Whatman-P 81 phosphocellulose). These were dried with a heat gun, washed in a Buchner-funnel with 41 water, and placed into scintillation vials containing $5 \mathrm{ml}$ Quickszint 2000 (Zinsser). This method was modified after the procedure of Markham [14].

\section{Enzyme purification}

a) Tyrosine decarboxylase

Frozen cells of Berberis stolonifera $(150 \mathrm{~g})$ were thawed under stirring in $0.1 \mathrm{M} \mathrm{KPO}_{4}^{2-}$ buffer $\mathrm{pH} 7.5$ containing $20 \mathrm{~mm} \beta$-mercaptoethanol. After $20 \mathrm{~min}$ the suspension was centrifuged at $12000 \times g$
(15 min). The supernatant was saturated to $70 \%$ $\left(\mathrm{NH}_{4}\right)_{2} \mathrm{SO}_{4}$ and centrifuged again. The pellet was resuspended in $10 \mathrm{mM} \mathrm{KPO}_{4}{ }^{2-}$ buffer at $\mathrm{pH} 7.5$ and separated from most of the phenols and alkaloids by passage through a Sephadex G-25 column $\left(70 \times 2.5 \mathrm{~cm}: 90 \mathrm{ml} / \mathrm{h}\right.$, elution buffer: $10 \mathrm{mM} \mathrm{KPO}_{4}{ }^{2-}$ $\mathrm{pH}$ 7.5). The protein containing eluates were combined $(63 \mathrm{ml})$ and concentrated by pressure filtration (YM 10; Amicon, Witten) to $20 \mathrm{ml}$. The protein solution was applied to a QAE-ion exchange column $(10 \times 2.5 \mathrm{~cm} ;$ Pharmacia, Freiburg; $30 \mathrm{ml} / \mathrm{h})$ and eluted with a $0-1 \mathrm{M} \mathrm{KCl}$ gradient in suspension buffer. Fractions with a $3.5 \mathrm{ml}$ volume were collected and those containing the enzyme (no's 67-76) were pooled and used as an enzyme source.

\section{b) Phenolase}

A pressure filtrate from Berberis stolonifera cells was prepared as described under a). The concentrate $(20 \mathrm{ml})$ was added to a hydroxylapatite column (BioRad, Richmond; $1 \times 10 \mathrm{ml}$, flow rate $20 \mathrm{ml} / \mathrm{h}$ ). The phenolase does not bind to the column material under these conditions and was eluted with the washings $(30 \mathrm{ml}, 10 \mathrm{~mm}$ phosphate buffer, $\mathrm{pH} 7.5)$. This fraction was added to a DEAE column (AmiconMatrex ${ }^{\mathrm{TM}}$ Cellufine-AH) where it was again eluted with the washings $(35 \mathrm{ml})$. The protein solution was concentrated (ultra filtration) and used as an enzyme source.

\section{c) Transaminase}

Frozen tissue of the species under investigation was thawed with stirring in $50 \mathrm{~mm} \mathrm{Na-pyrophosphate}$ buffer pH 7.0 containing $10^{-4} \mathrm{M}$ thiamine pyrophosphate and $10^{-4} \mathrm{M} \mathrm{MgCl}_{2}$. An equal amount of polyvinylpyrrolidone (Polyclar AT) was added. After $20 \mathrm{~min}$ the slurry was filtered through cheesecloth and centrifuged for $10 \mathrm{~min}(15000 \times \mathrm{g})$. The supernatant was saturated with $\left(\mathrm{NH}_{4}\right)_{2} \mathrm{SO}_{4}$ (to $70 \%$ ) and the precipitated protein sedimented. The pellet was resuspended in a small amount of extraction buffer and used as an enzyme source.

\section{d) p-Hydroxyphenylpyruvate decarboxylase}

Frozen tissue of Berberis stolonifera was extracted as given for tyrosine decarboxylase, however, all buffers used contained $20 \mathrm{~mm} \beta$-mercaptoethancl. The eluate from the Sephadex G-25 column was immediately applied to a DEAE-column $(15 \times 2.5 \mathrm{~cm}$. Ami- 
con-Matrex ${ }^{\mathrm{TM}}$ Cellufine- $\mathrm{AH}$ ) at a rate of $40 \mathrm{ml} / \mathrm{h}$. The enzyme was eluted in $5 \mathrm{ml}$ fractions. The fractions containing the enzyme were pooled $(60 \mathrm{ml})$ and concentrated by pressure filtration (Amicon) to $10 \mathrm{ml}$. The concentrated protein solution was applied to a gel filtration column $(100 \times 2.5 \mathrm{~cm}$, TSK-HW $55 \mathrm{~S}$, Merck) and eluted in $3 \mathrm{ml}$ fractions at $17 \mathrm{ml} / \mathrm{h}$ with $10 \mathrm{mM} \mathrm{KPO}_{4}{ }^{2-}$ buffer $\mathrm{pH}$ 7.5. The eluate was tested for activity and the enzyme containing fractions $(84-90)$ combined $(30 \mathrm{ml})$ and used as an enzyme source.

\section{e) Amineoxidase}

Frozen tissue of Berberis wilsoniae was extracted as given under a) for tyrosine decarboxylase. All buffers contained $20 \mathrm{~mm} \beta$-mercaptoethanol. The eluate of the Sephadex G-25 column was applied to a DEAE-column $(15 \times 2.5 \mathrm{~cm}$; flow rate $10 \mathrm{ml} / \mathrm{h})$. The elution buffer used was $10 \mathrm{mM} \mathrm{KPO}_{4}{ }^{2-}$ and a linear $\mathrm{KCl}$ gradient $(0-1 \mathrm{M} \mathrm{KCl})$ applied. Fractions $(2.5 \mathrm{ml})$ containing enzyme activity $(69-74$; total of $13 \mathrm{ml}$ ) were pooled, dialysed against $25 \mathrm{~mm}$ Tris/ $\mathrm{HCl}$ (pH 6.0, $20 \mathrm{~mm} \beta$-mercaptoethanol), and applied to a DEAE-HPLC column $(1.0 \times 25 \mathrm{~cm}$, Synchropak AX 300, SynChrom Inc. Linden, Indiana; $0-0.5 \mathrm{M}$ $\mathrm{NaCl}$; flow rate $3 \mathrm{ml} / \mathrm{min}$ ). Fractions of $3 \mathrm{ml}$ volume were collected. The amineoxidase was present in fractions $38-48$.

\section{f) ATP: L-Methionine-S-Adenosyltransferase}

$100 \mathrm{~g}$ frozen tissue of Berberis wilsoniae was extracted with $20 \mathrm{~mm}$ Tris-buffer $\mathrm{pH} 7.8$ containing $1 \mathrm{mM} \mathrm{MgCl}_{2}, 1 \mathrm{~mm}$ EDTA, $15 \%$ glycerol, and $20 \mathrm{~mm}$ $\beta$-mercaptoethanol. The slurry was pressed through cheesecloth and the liquid phase centrifuged at $15000 \times g$ for $15 \mathrm{~min}$. The supernatant was saturated with $\left(\mathrm{NH}_{4}\right)_{2} \mathrm{SO}_{4}$ to $70 \%$ and the precipitated protein centrifuged $(15 \mathrm{~min}, 15000 \times \mathrm{g})$. The pellet was taken up in extraction buffer and the protein solution subjected to gel filtration (Sephadex G-25, $70 \times 2.5 \mathrm{~cm}$, flow rate $90 \mathrm{ml} / \mathrm{h}, 7.5 \mathrm{ml}$ fractions). The column was eluted with extraction buffer. The protein containing fractions were combined $(50 \mathrm{ml})$ and applied to a DEAE-column $(15 \times 2.5 \mathrm{~cm}$, AmiconMatrex $^{\mathrm{TM}}$, flow rate $40 \mathrm{ml} / \mathrm{h}$ ). The column was equilibrated with extraction buffer, elution was carried out with a stepwise $\mathrm{KCl}$ gradient $(0.05,0.1,0.25,0.5$, $0.75,1 \mathrm{M}$ each $100 \mathrm{ml}$ ) in extraction buffer during a period of $8 \mathrm{~h}$. The enzyme appeared in the $0.1 \mathrm{M} \mathrm{KCl}$ fraction (fractions $57-69 ; 5.5 \mathrm{ml}$ fractions were collected). The enzyme containing fractions were used for characterization of the transferase.

\section{Results \\ Incorporation of potential precursors}

In the present study the incorporation of carrierfree ${ }^{14} \mathrm{C}$-labelled L-tyrosine, L-DOPA, tyramine, and dopamine into jatrorrhizine was investigated using vigorously growing callus tissue of $B$. canadensis. Each of the precursors was labelled at the carbon atom of the side chain adjacent to the aromatic ring. The alkaloid was isolated and degraded as depicted in Fig. 1. The distribution of radioactivity in the "upper" isoquinoline and "lower" benzylic portion was monitored after chemical degradation of the methylated alkaloid as shown in Fig. 1. As can be seen in Table I, high incorporation of all four potential precursors $(25$ to $35 \%)$ was observed in the protoberberine molecule. The incorporation of tyrosine into both halves of the alkaloid molecule follows the pattern already well established $[2,3]$. DOPA was predominantly incorporated (97\%) into the upper portion of the molecule, again being consistent with the classical pattern $[2,3]$. Since both halves of the protoberberine molecule are clearly derived from tyrosine, which labels the alkaloid with approximately equal efficiency, tyrosine cannot be metabolized solely via DOPA [3] and 3,4-dihydroxyphenylpyruvate as suggested earlier [4]. In order to further investigate the metabolic fate of tyrosine in this plant, its decarboxylation product, tyramine, was applied to the callus. As summarized in Table I, tyramine is incorporated up to about $75 \%$ into the isoquinoline and up to a surprisingly high value of $25 \%$ into the benzylic part of jatrorrhizine. On the other hand (carrier-free) $\left[{ }^{14} \mathrm{C}\right]$ dopamine, already possessing both aromatic hydroxyl groups required for the formation of the benzylic portion of norlaudanosoline, is unquestionably incorporated in a relatively small but significant proportion (15\%), but also to a lower extent than tyramine. This observation is at variance with a host of experiments conducted previously, showing that this amine is solely incorporated into the upper isoquinoline portion of these types of alkaloids [2]. In summary, all four potential precursors are incorporated well into the benzylisoquinoline alkaloid jatrorrhizine. Since we know from enzyme work $[8,9]$ that dopamine condenses both with $3,4-$ 


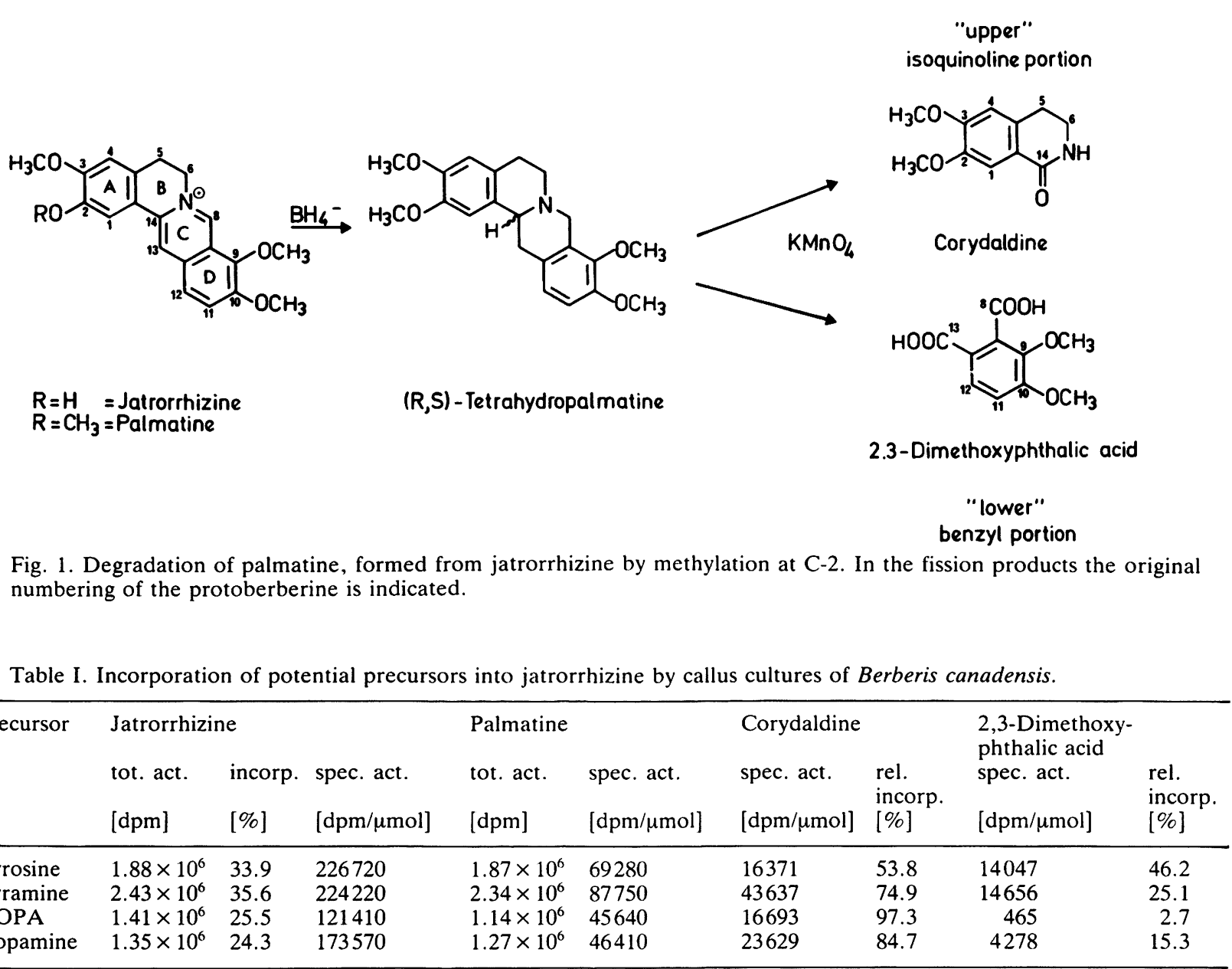

dihydroxyphenylacetaldehyde and also with $p$-hydroxyphenylacetaldehyde to form norlaudanosoline or norcoclaurine, the question remaining is by which enzymatic mechanisms the aromatic amino acids DOPA, tyramine and dopamine as well as both phenylacetaldehydes are formed.

\section{Enzymes of tyrosine metabolism}

\section{DOPA Decarboxylase}

Dopamine is the precursor of the upper portion of the isoquinoline system [2] and is formed by decarboxylation of DOPA. Decarboxylases acting on tyrosine and DOPA are readily found in plant tissue capable of synthesizing substituted phenylethylamines involved in secondary plant products [e.g. 15-18]. Since cell cultures of $B$. stolonifera elaborate considerable amounts of protoberberine alkaloids [10], this tissue was chosen to be checked for the presence of a decarboxylase acting on DOPA or tyrosine (see Fig. 2a). Tyrosine was the preferred substrate because of its higher stability in the crude cell extract. As shown in Table II, the enzyme was discovered in cell-free homogenates and was partially purified about 30 -fold. The pH-optimum of the enzyme was at 7.5 and the molecular weight was determined by gel filtration to be $47 \mathrm{kDa} \pm 10 \%$ (Table III). The most important property of the enzyme was, however, its substrate specificity. As clearly shown in Table III, the preferred substrate for this partially purified enzyme is DOPA (7.2 pkat/ mg protein) while tyrosine is decarboxylated only to about $10 \%$ of the rate of the dihydroxylated amino acid $(0.7 \mathrm{pkat} / \mathrm{mg})$. The nature of the enzymatic de- 


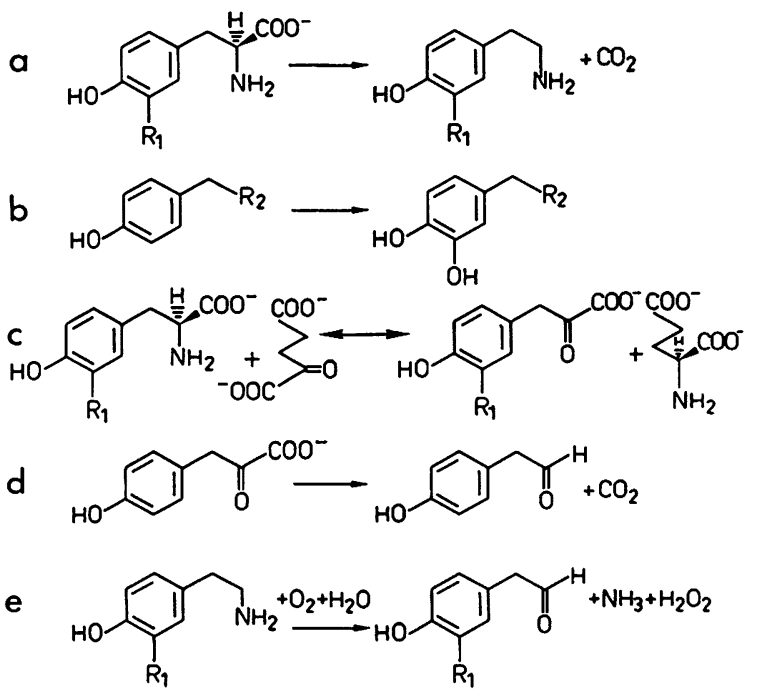

Fig. 2. Enzymes involved in tyrosine metabolism as investigated in this study. $a=$ DOPA decarboxylase, $b=$ Cresolase, $\mathrm{c}=$ Transaminase, $\mathrm{d}=p$-Hydroxyphenylpyruvate decarboxylase, $\mathrm{e}=$ Amineoxidase. $\mathrm{R}_{1}=\mathrm{H}=$ tyrosine, $\mathrm{R}_{1}=\mathrm{OH}=\mathrm{DOPA} /$ dopamine, $\mathrm{R}_{2}=\mathrm{CHNH}_{2}-\mathrm{COOH}=$ tyrosine, $\mathrm{R}_{2}=\mathrm{CH}_{2} \mathrm{NH}_{2}=$ tyramine, $\mathrm{R}_{2}=\mathrm{CHO}=$ $p$-hydroxyphenylacetaldehyde.

Table II. Partial purification of DOPA decarboxylase from Berberis stolonifera suspension cells.

\begin{tabular}{llllc}
\hline Purification step & $\begin{array}{l}\text { Total activity } \\
\text { [pkat] }\end{array}$ & $\begin{array}{l}\text { Specific activity } \\
\text { [pkat/mg] }\end{array}$ & $\begin{array}{l}\text { Recovery } \\
{[\%]}\end{array}$ & $\begin{array}{l}\text { Purification } \\
\text { [-fold] }\end{array}$ \\
\hline $\begin{array}{l}\text { Crude extract } \\
\begin{array}{l}\text { Ammoniumsulfate } \\
\text { precipitation (0-70\%) }\end{array}\end{array}$ & 77.7 & 0.09 & 100 & 1 \\
$\begin{array}{l}\text { Gel filtration on } \\
\text { Sephadex G-25 }\end{array}$ & 251.0 & 0.13 & 106 & 1.4 \\
$\begin{array}{l}\text { QAE-Sephadex } \\
\text { chromatography }\end{array}$ & 37.1 & 0.89 & 323 & 9.5 \\
\hline
\end{tabular}

Table III. Some properties of the six enzymes potentially involved in the biosynthesis of benzylisoquinoline alkaloids using suspension cells of Berberis stolonifera as enzyme source.

\begin{tabular}{|c|c|c|c|c|c|c|}
\hline Enzyme & $\begin{array}{l}\text { DOPA } \\
\text { decarboxyl- } \\
\text { ase }\end{array}$ & $\begin{array}{l}\text { Phenol- } \\
\text { oxidase }\end{array}$ & $\begin{array}{l}\text { Amino- } \\
\text { transferase }\end{array}$ & $\begin{array}{l}p \text {-OH-phenyl- } \\
\text { pyruvate } \\
\text { decarboxylase }\end{array}$ & $\begin{array}{l}\text { Amine- } \\
\text { oxidase }\end{array}$ & $\begin{array}{l}\text { Methionine- } \\
\text { adenosyl } \\
\text { transferase* }\end{array}$ \\
\hline $\begin{array}{l}\text { Crude homogenate } \\
\text { pkat/litre medium } \\
\text { pkat/g dwt }\end{array}$ & $\begin{array}{r}395 \\
0.16\end{array}$ & $\begin{array}{r}868 \\
0.36\end{array}$ & $\begin{array}{r}3110 \\
1.3\end{array}$ & $\begin{array}{r}581 \\
0.24\end{array}$ & $\begin{array}{l}55 \\
0.02\end{array}$ & $\begin{array}{l}73 \\
0.03\end{array}$ \\
\hline Molecular weight $(\mathrm{kDa})$ & 47 & 54 & - & 30 & 89 & 55 \\
\hline pH-Optimum & 7.5 & 8.5 & 7.5 & 6.5 & 7.8 & $8.5-9.5$ \\
\hline $\begin{array}{l}\text { Substrate } \\
\text { transformation [\%] }\end{array}$ & $\begin{array}{l}\text { DOPA } 100 \\
\text { Tyrosine } 9\end{array}$ & $\begin{array}{l}\text { Tyrosine } 100 \\
\text { Tyramine } 100 \\
\text { 4-Hydroxy- } \\
\text { phenylacet- } \\
\text { aldehyde } 80\end{array}$ & $\begin{array}{l}\text { Tyrosine } 100 \\
\text { DOPA } 85\end{array}$ & - & $\begin{array}{l}\text { Tyramine } 100 \\
\text { Dopamine } 5\end{array}$ & - \\
\hline
\end{tabular}

\footnotetext{
* From Berberis wilsoniae.
} 
carboxylation product (dopamine or tyramine) was verified at each step by TLC.

\section{Phenoloxidase}

Both tyrosine and possibly tyramine, the decarboxylation product of tyrosine, have to be hydroxylated in the meta position of the aromatic ring to yield DOPA and dopamine respectively, the known precursors of the upper ring portion of benzylisoquinoline alkaloids. The enzyme involved in this reaction is regarded to be the cresolase activity of polyphenoloxydase (Fig. 2b) [15, 17]. The enzyme was monitored be measuring the release of tritium from the 3-position of ring labelled L-tyrosine. No $\mathrm{NIH}$-shift was found to occur during this reaction. While in Papaver somniferum this enzyme occurs in two forms, one readily released from organelles occurring in latex and one in membrane bound form [19], the Berberis enzyme investigated here is readily soluble. The cresolase was purified about 55 -fold as shown in Table IV. The enzyme shows a pH-optimum at 8.5 and a molecular weight of $54 \mathrm{kDa} \pm$ $10 \%$ (Table III), as determined by gel filtration on a standardized HPLC column and by SDS gel electrophoresis. The enzyme displays a $K_{\mathrm{M}}$ of $40 \mu \mathrm{M}$ for both tyrosine and tyramine and a $K_{\mathrm{M}}$ of $50 \mu \mathrm{M}$ for $p$-hydroxyphenylacetaldehyde. In all three cases the expected monohydroxylated product formed was checked by TLC using authentic standards. The enzyme was fully inhibited by the copper chelator diethyldithiocarbamate at a concentration of $0.5 \mathrm{~mm}$ (50\% inhibition at $0.1 \mathrm{~mm}$ ).

\section{Transaminase}

L-DOPA may be metabolized in isoquinoline containing plants in at least two ways. Decarboxylation provides dopamine, which is the established precur- sor of the upper portion of the alkaloid. Transamination (Fig. 2c), however, both of tyrosine as well as DOPA could yield the corresponding phenylpyruvates which could decarboxylate to yield either $p$ hydroxyphenylacetaldehyde or its dihydroxylated derivative [11]. Enzyme activities for transaminases involving tyrosine and DOPA have previously been found in Papaver somniferum [15]. Using an enzyme assay which is based on the release of tritium from the 2- (and partially 3-)position of $\left[2,3-{ }^{3} \mathrm{H}\right]$ tyrosine [20] and inserting $\alpha$-ketoglutarate as an amino group acceptor, the enzyme was assayed in the presence of pyridoxalphosphate. Tyrosine and DOPA transamination was found (Table V) to occur in a large number of cell cultures all known to produce isoquinoline alkaloids. The enzyme of $B$. stolonifera had a pH-optimum at 7.5 and was slightly less active on DOPA $(85 \%)$ as compared with tyrosine (Table III).

\section{4. p-Hydroxyphenylpyruvate decarboxylase}

The formation of the 1-benzylisoquinoline structure requires the condensation of dopamine with either $p$-hydroxyphenylacetaldehyde or 3,4-dihydroxyphenylacetaldehyde $[8,9]$ to yield norcoclaurine as precursor for the coclaurine derived alkaloids or norlaudanosoline believed to be the precursor of the reticuline derived alkaloids. One possibility to furnish the required aldehyde is by decarboxylation of the aromatic pyruvates (Fig. 2d). This reaction has not been previously described to occur in higher plants but was found to occur during phenylalanine metabolism, for instance, in Achromobacter eurydice [21]. In this bacterium, phenylpyruvate is decarboxylated by a specific enzyme to phenylacetaldehyde, however, $p$-hydroxyphenylpyruvate does not serve as a substrate for this catalyst.

Table IV. Partial purification of phenoloxidase (tyrosine hydroxylation) from Berberis stolonifera suspension cells.

\begin{tabular}{lcccc}
\hline Purification step & $\begin{array}{l}\text { Total activity } \\
\text { [pkat] }\end{array}$ & $\begin{array}{l}\text { Specific activity } \\
\text { [pkat/mg] }\end{array}$ & $\begin{array}{l}\text { Recovery } \\
{[\%]}\end{array}$ & $\begin{array}{l}\text { Purification } \\
\text { [-fold] }\end{array}$ \\
\hline $\begin{array}{l}\text { Crude extract after ammoniumsulfate } \\
\text { precipitation }(0-70 \%)\end{array}$ & 1070 & 0.75 & 100 & 1 \\
Gel filtration on Sephadex G-25 & 1090 & 7.08 & 102 & 9.4 \\
Hydroxylapatite chromatography & 837 & 21.4 & 78 & 28.5 \\
DEAE-Cellufine chromatography & 611 & 41.3 & 73 & 55.0 \\
\hline
\end{tabular}


Table V. Survey of DOPA and tyrosine transaminase in cell-free extracts of cell suspension cultures from isoquinoline alkaloid containing species.

\begin{tabular}{|c|c|c|c|c|}
\hline Cell culture & $\begin{array}{l}\text { DOPA } \\
\text { specific } \\
\text { activity } \\
\text { [pkat/mg] }\end{array}$ & $\begin{array}{l}\text { total } \\
\text { activity } \\
\text { [pkat/l } \\
\text { medium] }\end{array}$ & $\begin{array}{l}\text { Tyrosine } \\
\text { specific } \\
\text { activity } \\
\text { [pkat } / \mathrm{mg} \text { ] }\end{array}$ & $\begin{array}{l}\text { total } \\
\text { activity } \\
\text { [pkat/l } \\
\text { medium] }\end{array}$ \\
\hline Berberis stolonifera & 3.7 & 2639 & 4.4 & 3113 \\
\hline B. aristata & 0.4 & 751 & 1.6 & 2998 \\
\hline B. wilsoniae & 1.3 & 1049 & 8.2 & 1958 \\
\hline B. henryana & 0.3 & 489 & 1.6 & 2208 \\
\hline Eschscholzia californica & 0.2 & 143 & 0.4 & 318 \\
\hline E. lobbii & 1.8 & 1283 & 0.4 & 276 \\
\hline E. pulchella & 0 & 0 & 0.8 & 277 \\
\hline Corydalis vaginans & 0.3 & 263 & 0.2 & 121 \\
\hline C. sempervirens & 1.6 & 1217 & 0.8 & 609 \\
\hline Meconopsis cambrica & 2.8 & 1433 & 2.3 & 1215 \\
\hline Dicentra spectabilis & 0.2 & 369 & 0.1 & 233 \\
\hline Thalictrum dipterocarpum & 4.6 & 3716 & 2.8 & 2256 \\
\hline$T$. petaloides & 0.5 & 208 & 0.3 & 1054 \\
\hline Papaver somniferum & 1.6 & 1208 & 0.3 & 509 \\
\hline
\end{tabular}

We here present a preliminary report on an enzyme from $B$. stolonifera which decarboxylates $p$-hydroxyphenylpyruvate to $p$-hydroxyphenylacetaldehyde and which we termed $p$-hydroxyphenylpyruvate decarboxylase. The enzyme was purified about 30 -fold as depicted in Table VI. It has a pH-optimum at 6.5 and a molecular weight of $30 \mathrm{kDa}$ (by HPLC gel filtration) (Table III). The $K_{\mathrm{M}}$ for the $p$-hydroxylated substrate is $670 \mu \mathrm{M}$; the 3,4-dihydroxylated phenylpyruvate could not be measured since it decomposed too rapidly under the assay conditions. The product of the enzymic reaction was shown by TLC as well as by formation of the 2,4-dinitrophenylhydrazone to be the aldehyde. The enzyme was found to occur in crude protein extracts of several isoquinoline pro- ducing plant cell cultures such as: $B$. aristata (206), $B$. julianae (468), B. stolonifera (581), B. regeliana (81), Tinospora caffra (176), T. cordifolia (102), Eschscholzia californica (31), Thalictrum dipterocarpum (212), T. minus (130); values given as pkat/litre of suspension culture. A more detailed characterization of the decarboxylase is currently in progress. This new enzyme is regarded to be located at a crucial metabolic branch point: DOPA is channelled to dopamine to produce the upper portion of the isoquinoline skeleton; $p$-hydroxyphenylpyruvate or 3,4dihydroxyphenylpyruvate, derived from tyrosine or DOPA, are decarboxylated to the corresponding phenylacetaldehydes which represent the benzylic portion of the isoquinoline aldehydes.

Table VI. Partial purification of 4-hydroxyphenylpyruvate decarboxylase from Berberis stolonifera suspension cells.

\begin{tabular}{lllll}
\hline Purification step & $\begin{array}{l}\text { Total activity } \\
\text { [pkat] }\end{array}$ & $\begin{array}{l}\text { Specific activity } \\
\text { [pkat/mg] }\end{array}$ & $\begin{array}{l}\text { Recovery } \\
{[\%]}\end{array}$ & $\begin{array}{l}\text { Purification } \\
{[\text {-fold] }}\end{array}$ \\
\hline $\begin{array}{l}\text { Crude extract after gel } \\
\text { filtration on Sephadex G-25 }\end{array}$ & 605 & 0.76 & 100 & 1 \\
$\begin{array}{l}\text { DEAE-Cellufine } \\
\text { chromatography }\end{array}$ & 456 & 8.09 & 75 & 11 \\
$\begin{array}{l}\text { TSK-HW 55S gel filtration } \\
\text { chromatography }\end{array}$ & 158 & 21.1 & 26 & 29 \\
\hline
\end{tabular}


Table VII. Partial purification of amineoxidase from Berberis stolonifera suspension cells.

\begin{tabular}{llclc}
\hline Purification step & $\begin{array}{l}\text { Total activity } \\
\text { [pkat] }\end{array}$ & $\begin{array}{l}\text { Specific activity } \\
\text { [pkat/mg] }\end{array}$ & $\begin{array}{l}\text { Recovery } \\
{[\%]}\end{array}$ & $\begin{array}{l}\text { Purification } \\
\text { [-fold] }\end{array}$ \\
\hline $\begin{array}{l}\text { Crude extract after gel } \\
\text { filtration on Sephadex G-25 }\end{array}$ & 242 & 1.5 & 100 & 1 \\
$\begin{array}{l}\text { DEAE-Cellufine } \\
\text { chromatography }\end{array}$ & 54.1 & 2.1 & 22 & 1.4 \\
DEAE-HPLC & 7.7 & 256.9 & 3.2 & 171.3 \\
\hline
\end{tabular}

\section{Amineoxidase}

An alternative route to the phenylacetaldehydes is by oxidation of the aromatic amines tyramine or dopamine (Fig. 2e). It has been known for a long time that amineoxidases in plants act [22] on substrates such as tyramine. Amineoxidase was discovered in cell cultures of Berberis, the partial purification being shown in Table VII. The 170 -fold purified enzyme has a molecular weight of $89 \mathrm{kDa} \pm 10 \%$ and a pH-optimum at 7.8 (Table III). It could be demonstrated that dopamine was oxidized at only $5 \%$ of the rate of tyramine. In both cases the aldehydes were identified as reaction products. As seen in Table III, however, the absolute enzyme concentration was relatively weakly expressed in this tissue. As a comparison a crude homogenate of suspension cells of Syringa vulgaris, a tissue which is known for the production of salidroside and verbascoside [18] (both compounds contain either 4-hydroxy- or 3,4-dihydroxyphenylethanol), was tested for amineoxidase. The activity of the enzyme in this tissue was $67 \mathrm{pkat} / \mathrm{mg}$ protein and as high as 25000 pkat/l medium (Table VIII). Nevertheless, the amineoxidase was clearly

Table VIII. Survey of amineoxydase in cell-free extracts of cell suspension cultures from isoquinoline alkaloid containing species and Syringa, containing $\mathrm{C}_{6}-\mathrm{C}_{2}$ alcohol glycosides [29].

\begin{tabular}{llc}
\hline Cell culture & $\begin{array}{l}\text { Specific activity } \\
\text { [pkat/mg] }\end{array}$ & $\begin{array}{l}\text { Total activity } \\
\text { [pkat/l medium] }\end{array}$ \\
\hline B. stenophylla & 0.87 & 145 \\
B. aristata & 0.76 & 140 \\
B. circumserrata & 0.70 & 182 \\
B. stolonifera & 0.75 & 55 \\
Tinospora caffra & 1.29 & 67 \\
Syringa vulgaris & 66.9 & 25000 \\
\hline
\end{tabular}

detectable in the alkaloid containing tissues of different Berberis species which indicates that the formation of the aromatic aldehydes would be possible by firstly converting the aromatic amino acids to the amines, which in turn could be further oxidized to the aldehydes.

\section{Methionineadenosyl transferase}

SAM, which is formed by the transfer of the adenosyl group from ATP to the sulfur atom of methionine, is the universal methyl group donator for all of the $\mathrm{O}$ - and $\mathrm{N}$-methyl groups as well as for methylenedioxy groups found in isoquinoline alkaloids $[2,11]$. Recently, multiple forms of the transferase were described in plants [25] and the enzyme has been investigated thoroughly in peas and barley $[23,24]$. In order to prove the presence of this enzyme in Berberis cultures, the crude cell-free homogenates were analysed for activity. The highest enzyme activity was found to occur in $B$. wilsoniae. The enzyme was partially purified (18-fold) (Table IX) and its molecular weight determined to be $55 \mathrm{kDa}$. The pH-optimum is at $8.5-9.5$ (Table III) and is considerably higher than the previously reported methionineadenosyl transferases [23, 24]. The Berberis enzyme is also inhibited by potassium phosphate buffer $(50 \%$ inhibition at $12.5 \mathrm{~mm}$ $\mathrm{KPO}_{4}{ }^{2-}$ ). The $K_{\mathrm{M}}$-value for methionine is $4 \mu \mathrm{M}$ at saturating concentrations of the second substrate (ATP). In spite of the low catalytic activity of the methionineadenosyl transferase in these suspension cultures, it must be this enzyme which provides the methyl donor [11] for protoberberine in the Berberis cultures.

Select properties of the enzymes of tyrosine metabolism investigated here from Berberis cell suspension cultures are summarized in Table III. 
Table IX. Partial purification of ATP: L-Methionine-S-Adenosyltransferase.

\begin{tabular}{|c|c|c|c|c|}
\hline Purification step & $\begin{array}{l}\text { Total activity } \\
\text { [pkat] }\end{array}$ & $\begin{array}{l}\text { Specific activity } \\
{[\mathrm{pkat} / \mathrm{mg}]}\end{array}$ & $\begin{array}{l}\text { Recovery } \\
{[\%]}\end{array}$ & $\begin{array}{l}\text { Purification } \\
\text { [-fold] }\end{array}$ \\
\hline Crude extract & 10.6 & 0.02 & 100 & 1 \\
\hline $\begin{array}{l}\text { Ammoniumsulfate } \\
\text { precipitate }(0-70 \%) \\
\text { Gel filtration on }\end{array}$ & 19.2 & 0.04 & 181 & 2 \\
\hline $\begin{array}{l}\text { Sephadex G-25 } \\
\text { DEAE-Cellufine }\end{array}$ & 36.5 & 0.12 & 344 & 5.5 \\
\hline chromatography & 19.9 & 0.40 & 187 & 18.2 \\
\hline
\end{tabular}

\section{Discussion}

All four potential precursors of the protoberberine alkaloids, tyrosine, DOPA, tyramine and dopamine were incorporated between 25 and 35 percent using the callus feeding technique over a period of 5 days. No scrambling of the labelled precursor occurred under these prolonged feeding conditions as had also been observed in studies with intact plants [e.g. 26]. Degradation of the labelled jatrorrhizine showed, in the case of tyrosine application, that this molecule was incorporated to an equal extent into both the upper and the lower half of the benzylisoquinoline molecule. This result is consistent with the classical pattern established previously [2]. Also, the finding that DOPA is incorporated only $(97 \%)$ into the upper half (rings $\mathrm{A}$ and $\mathrm{B}$ ) of the protoberberine molecule is consistent with numerous previous reports $[2,3]$. The fact that tyramine serves as a precursor (25\% incorporation) of the lower benzyl portion (ring D) of the protoberberine molecule is new. However, tyramine, as a precursor of isoquinoline alkaloids, has hardly ever been studied in the past. The incorporation of dopamine $(15 \%)$ into the benzylic portion of jatrorrhizine is contradictory to previous reports [2]. This discrepancy may be due to the fact that in our experiments very small amounts of substrate with high specific activity were applied to a vigorously growing tissue, selected for high alkaloid production. Under these conditions the precursor immediately reached the alkaloid synthesizing cells without the necessity of being transported over long distances as in the case of whole plant feeding experiments. The application of a potential precursor directly to the alkaloid synthesizing cells, as in the case of callus feeding, may be of considerable advantage especially if the precursor is chemically and biologically (phenoloxidases) unstable as, for instance, dopamine. Furthermore, the dopamine pool which in some plants (e.g. Papaver) can be extremely large [27], could lead to an enormous dilution of the labelled precursor administered resulting in a low absolute incorporation. As a result of our callus feeding experiments summarized in Table I, we can conclude that in accordance with the literature $[2,3]$ tyrosine and DOPA are incorporated according to the classical scheme, which rules out the possibility that DOPA is incorporated via norlaudanosolinecarboxylic acid as has been previously suggested [4]. The incorporation of both amines, tyramine and dopamine, into the benzylic portion of the protoberberine molecule demonstrates, however, that an amineoxidase must be active in the tissue to furnish the corresponding phenylacetaldehydes. These aldehydes are required for the enzymatic condensation with dopamine $[8,9]$ to yield the benzylisoquinoline structure. Theoretically, the required aldehydes could also be generated via decarboxylation of the $p$-hydroxy- or 3,4-dihydroxyphenylpyruvates in an analogous manner, as has been shown in the formation of phenylacetaldehyde from phenylpyruvate by a bacterial enzyme involved in phenylalanine degradation [21].

In order to test these possibilities, the enzymes for tyrosine metabolism were investigated using Berberis cell cultures which produce large amounts of protoberberines [10]. We sought to elucidate the pathway of precursor formation by demonstrating the presence of the enzymes involved in tyrosine metabolism in these cultures. An aromatic amino acid decarboxylase, transaminase and phenoloxidase had already been demonstrated 20 years ago to be present in the opium-containing Papaver [15], a fact which was later confirmed with more sophisticated techniques $[16,17]$. In our study using cultured cells 
of Berberis, a decarboxylase was found which was considerably more active with DOPA than with tyrosine. In both cases the corresponding amine was formed which serves as a precursor for the upper and, via amineoxidase (see below), also for the lower part of the isoquinoline skeleton. This enzyme is a member of the general type of aromatic amino acid decarboxylases found in plants [28]. Transaminase was also present, its activity about equivalent with DOPA and with tyrosine. If tyrosine (in Berberis) is also exclusively formed from prephenate via arogenate, as has been documented for other plants [29], then a major function of the transaminase would consist of the provision of the phenylpyruvates for decarboxylation to furnish the phenylacetaldehydes required for the benzylisoquinoline structure. Furthermore, it has been established that the aromatic amino acid amino transferases may be highly substrate specific [30]. The activity of phenoloxidase was easily demonstrated in the Berberis cells. Tyrosine, tyramine, and $p$-hydroxyphenylacetaldehyde were about equally well hydroxylated by the phenolase. The high incorporation (75\%) of tyramine observed here (Table I) into the upper dopamine-derived portion of jatrorrhizine, clearly demonstrates the hydroxylation of tyramine to dopamine, which is certainly catalysed by the phenolase. It is of interest that the phenolases seem to be highly species specific as judged by their physical properties. The comparison of the properties ( $\mathrm{pH}, \mathrm{MW}$ etc.) of phenoloxidase from Papaver [15, 16], Mucuna [31] or Berberis does not illustrate an uniform pattern. One can assume that the phenoloxidase observed here is responsible (at least) for the formation of DOPA from tyrosine as well as for the formation of dopamine from tyramine. The phenolase occupies a central role in supplying the metahydroxyl group in the aromatic ring of dopamine, the ultimate precursor of ring A of the alkaloids. The incorporation of the aromatic amines into the lower benzyl ring has been observed here for the first time. This observation makes it necessary to assume the presence of an amineoxidase which is known to occur abundantly in plants [22]. Amineoxidase, acting mainly on tyramine and less on dopamine was found to occur in Berberis. The activity based on pkat/g tissue (dwt) was only 0.02 , that is approximately $10 \%$ of the other enzymes of tyrosine metabolism in this tissue. The enzyme activity, however, was in the same order of magnitude as methionineadenosyl transferase $(0.03 \mathrm{pkat} / \mathrm{g})$ and this enzyme is known to provide all of the methyl groups of the protoberberines (in the case of jatrorrhizine it is $4 \mathrm{~mol}$ of methyl groups per mol of norlaudanosoline). Either there exist for both enzymes membrane-bound forms which are not extracted by the application of our usual extraction procedure or both enzymes are readily inactivated during the extraction process (which is unlikely since the amineoxidase is an unusually stable enzyme [22]). The possibility also exists that these low enzyme activities observed are sufficiently high to provide the precursor aldehydes or activated methyl groups required for the protoberberine alkaloids. Up to now it has not been possible to judge the flux of precursors into the alkaloids under in vivo conditions. The amineoxidase (Fig. 2e) in combination with the tyrosine decarboxylase (Fig. 2a) could account for the formation of the phenylacetaldehydes required for isoquinoline alkaloid formation. Further reduction of the aldehyde to the alcohol by action of an alcohol dehydrogenase and NADH as cosubstrate could also account for the formation of the hydroxyphenylethanol moiety of the glycosides verbascoside and salidroside [18] which are assumed to be formed from tyramine [32]. This alcohol dehydrogenase in combination with an exceptionally high activity of the amineoxidase was observed in Syringa vulgaris cell cultures. Besides the oxidation of aromatic amines to the corresponding aldehydes by the action of amineoxidase, the aldehydes can be generated by decarboxylation of the phenylpyruvates (see above and [21]). This decarboxylase, acting on p-hydroxyphenylpyruvate, was discovered in the Berberis tissue. $p$-Hydroxyphenylacetaldehyde was demonstrated as the reaction product. Future research has to distinguish by which of the alternate routes phenylacetaldehydes are generated, either by amine oxidation or by decarboxylation of the phenylpyruvates. Research on the biosynthesis of hydroxyphenylethanols will help to clarify this issue and hopefully allow a generalisation by which pathway $\mathrm{C}_{6}-\mathrm{C}_{2}$ units are formed in higher plants.

A metabolic scheme taking into account the results presented in this paper from precursor feeding and enzyme work is shown in Fig. 3. Arogenate or $p$-hydroxyphenylpyruvate [29] have to be regarded as precursors of tyrosine, the precursor of both the isoquinoline and benzylic portion of protoberberine alkaloids. Tyrosine is hydroxylated by action of phenoloxidase to DOPA, which in turn can either be 




Fig. 3. Biosynthetic sequence leading from prephenate via tyrosine to the building blocks of the benzylisoquinoline alkaloids: dopamine, 3,4-dihydroxyphenylacetaldehyde and 4-hydroxyphenylacetaldehyde.

decarboxylated to dopamine or transaminated to 3,4-dihydroxyphenylpyruvate. 3,4-Dihydroxyphenylacetaldehyde is formed either from dopamine by way of an amineoxidase or via decarboxylation of 3,4dihydroxyphenylpyruvate. The incorporation of dopamine into the benzylic portion of jatrorrhizine is evidence for the amineoxidase pathway. The presence of a phenylpyruvate decarboxylase yielding the dihydroxylated aldehyde is also likely. Both pathways cannot yet be differentiated. Exactly the same situation holds true for the formation of 4-hydroxyphenylacetaldehyde, which could be formed from tyramine by oxidation, or from 4-hydroxyphenylpyruvate by decarboxylation. The 1-benzylisoquinoline alkaloid precursors norcoclaurine or norlaudanosoline are then formed by the synthase $[8,9]$ which condenses 4-hydroxyphenylacetaldehyde or 3,4-di- hydroxyphenylacetaldehyde with dopamine. There could also exist a separate route from the tyraminederived norcoclaurine to the protoberberines. The findings presented here are compatible with but cannot completely resolve the statement of $\mathrm{I}$. D. Spenser [2] that "the two $\mathrm{C}_{6}-\mathrm{C}_{2}$ units derived from tyrosine which are incorporated into the alkaloids under discussion differ from one another".

\section{Acknowledgements}

We thank Miss Claudia Höcketstaller for excellent technical assistance. The linguistic help of R. Stadler and Dr. T. M. Kutchan in the preparation of this manuscript is gratefully acknowledged. This work was supported by SFB of Deutsche Forschungsgemeinschaft, Bonn, and Fonds der Chemischen Industrie. 
[1] E. Winterstein and G. Trier, Die Alkaloide, Gebrüder Bornträger, Berlin 1910.

[2] I. D. Spenser, in: Comprehensive Biochemistry 20, 231 (1968).

[3] H. L. Holland, P. W. Jeffs, T. M. Capps, and D. B. MacLean, Can. J. Chem. 57, 1588 (1979).

[4] M. L. Wilson and C. J. Coscia, J. Am. Chem. Soc. 97, 431 (1975).

[5] A. R. Battersby, R. C. F. Jones, and R. Kazlauskas, Tetrahedron Lett. 1975, 1873.

[6] T. Tewary, D. S. Bhakuni, and R. S. Kapil, Chem. Comm. 1975, 554.

[7] I. Scott, S.-L. Lee, and T. Hirata, Heterocycles 11, 159 (1978).

[8] M. Rueffer, H. El-Shagi, N. Nagakura, and M. H. Zenk, FEBS Lett. 129, 5 (1981).

[9] M. H. Schumacher, M. Rueffer, N. Nagakura, and M. H. Zenk, Planta Medica 48, 212 (1983).

[10] H. Hinz and M. H. Zenk, Naturwissenschaften 67, 620 (1981).

[11] M. H. Zenk, M. Rueffer, M. Amann, B. DeusNeumann, and N. Nagakura, J. Nat. Prod. 48, 725 (1985).

[12] E. M. Linsmaier and F. Skoog, Physiol. Plant. 18, 100 (1965).

[13] M. M. Bradford, Anal. Biochem. 72, 248 (1976).

[14] G. D. Markham, E. W. Hafner, C. W. Tabor, and H. Tabor, J. Biol. Chem. 225, 9082 (1980).

[15] A. Jindra, A. Kovács, Z. Pitterová, and M. Pšenák, Phytochemistry 5, 1303 (1966).

[16] M. F. Roberts and M. D. Antoun. Phytochemistry 17, 1083 (1978).
[17] M. F. Roberts, D. McCarthy, T. M. Kutchan, and C. J. Coscia, Arch. Biochem. Biophys. 222, 599 (1983).

[18] C. C. S. Chapple, M. A. Walker, and B. E. Ellis, Planta 167, 101 (1986).

[19] M. F. Roberts, Phytochemistry 13, 119 (1974).

[20] H. Holländer and N. Amrhein, Planta 152, 374 (1981).

[21] T. Asakawa, H. Wada, and T. Yamano, Biochim. Biophys. Acta 170, 375 (1968).

[22] R. H. Kenten and P. J. G. Mann, Biochem. J. 50, 360 (1952).

[23] H. Aarnes, Plant Sci. Lett. 10, 381 (1977).

[24] C. Lillo and H. Aarnes, Biochem. Physiol. Pflanzen 175, 104 (1980).

[25] O. Dogbo and B. Camana, Compt. rend. Ser. III. 303, 93 (1986).

[26] I. Monkovic and I. D. Spenser, Proc. Chem. Soc. 1964, 223.

[27] T. M. Kutchan, S. Ayabe, and C. J. Coscia, in: The Chemistry and Biology of Isoquinoline Alkaloids (Ed. J. D. Phillipson et al.), p. 281, Springer, Heidelberg 1985.

[28] K. Hosoi. Plant Cell Physiol. 15, 429 (1974).

[29] J. A. Connelly and E. E. Conn, Z. Naturforsch. 41c, 69 (1986).

[30] T. Noguchi and S. Hayashi, J. Biol. Chem. 255, 2267 (1980).

[31] H. J. Wichers, G. J. Peetsma, Th. M. Malingre, and H. J. Huizing, Planta 162, 334 (1984).

[32] B. E. Ellis, Phytochemistry 22, 1941 (1983). 